\title{
Chemical Composition and Functional Properties of Selected Seaweeds from the Kenya Coast
}

\author{
Eric N. Muraguri ${ }^{1}$, Joseph G. Wakibia ${ }^{2}$, \& John N. Kinyuru ${ }^{1}$ \\ ${ }^{1}$ Department of Food Science and Technology, Jomo Kenyatta University of Agriculture and Technology, Kenya \\ ${ }^{2}$ Department of Botany, Jomo Kenyatta University of Agriculture and Technology, Kenya \\ Correspondence: Eric N. Muraguri, Department of Food Science and Technology, Jomo Kenyatta University of \\ Agriculture and Technology, Po. Box 19386, Nairobi 00100, Kenya. E-mail: muranyoro@yahoo.co.uk
}

Received: September 1, 2016

Accepted: September 29, $2016 \quad$ Online Published: November 21, 2016

doi:10.5539/jfr.v5n6p114

URL: http://dx.doi.org/10.5539/jfr.v5n6p114

\begin{abstract}
The aim of the study was to determine the chemical and functional properties of five Kenyan seaweed species namely; (Hypnea musciformis, Eucheuma denticulatum, Laurencia intermedia, Sargassum oligocystum, Ulva fasciata) as a potential fat replacer in chicken sausage processing. The proximate composition was investigated using the standard AOAC methods, while the nitrogen-free extract (NFE) was determined by weight difference of the proximate components. The seaweeds were analyzed for mineral composition using atomic absorption spectrophotometry while the fatty acid profile was determined by gas chromatography. The water holding capacity and the emulsion capacity of the seaweed were determined using AACC procedures. The highest proximate component was NFE $(65.06 \%)$ while the least was crude fat $(0.87 \%)$. Among the nine minerals analyzed, calcium was the highest $(1185.29 \mathrm{mg} / 100 \mathrm{~g})$ while lead was not detected. Saturated fatty acids (SFA) were the highest with a range of 53.03-71.05\% followed by monounsaturated fatty acids (4.83-17.71\%) and polyunsaturated fatty acids (PUFA) $(2.75-10.13 \%)$. The highest emulsifying activity was obtained in Ulva fasciata (75.66 \%) and Eucheuma denticulatum (75.69 \%) while the lowest was obtained in Sargassum oligocystum (59.19\%). The highest water holding capacity was obtained in Sargassum oligocystum $(13.75 \mathrm{ml} / \mathrm{g})$ while the lowest was recorded in Eucheuma denticulatum $(8.42 \mathrm{ml} / \mathrm{g})$ and Ulva fasciata $(9.16 \mathrm{ml} / \mathrm{g})$. The findings of this study demonstrated the potential of seaweeds in improving the chemical and functional characteristics of processed foods.
\end{abstract}

Keywords: chemical composition, fatty acid, functional properties, mineral composition seaweed

\section{Introduction}

Seaweed is a common term for marine macroalgae. They are classified based on their chemical and nutrition composition as phaeophyta (brown algae), rhodophyta (red algae) and chlorophyta (green algae) (Dawczynski et al., 2007). The seaweeds are used as sources of minerals, phycocolloids and food. Seaweeds are largely consumed as human food in Japan, Vietnam, Korea, China, Indonesia, Philippines and Taiwan (Dawes, 1998). The production of seaweeds is increasing (Azad \& Xiang, 2012) due to interest in utilization in the food industry (Gupta \& Abu-Ghannam, 2011) and the potential of therapeutic use against cancer, diabetes and other degenerative conditions (Mohamed et al., 2012). About 150 out of 250 species of commercially used seaweeds are consumed in fresh or dry form and the rest of the species are used as animal feeds, fertilizer, fungicide, herbicides and various industrial applications (Fleurence, 1999; Kumari et al., 2010).

Seaweeds are important sources of macronutrients such as carbohydrates, proteins, lipids, fiber and micronutrients such as vitamins and minerals as well as other bioactive compounds (Ortiz et al., 2006). It is therefore presumed that consumption of seaweed may help in reducing obesity, undesirable lipoproteins and minimize the risk of coronary heart disease (Benjama and Masniyom, 2011). Seaweeds vary greatly in nutrient and chemical composition due to environmental factors such as salinity, water temperature and nutrients (Dawes, 1998). These variations may promote or inhibit the biosynthesis of biological compounds, thus affecting nutritional composition (Lobban et al., 1985). The protein of the macroalgae has been reported to possess all the essential amino acids, which may vary depending on the season. In addition, the macroalgae contain an estimated $1-6 \mathrm{~g}$ of fat per $100 \mathrm{~g}$. (Fleurence et al., 1994). According to van Ginneken et al., (2011), red and brown algae contains polyunsaturated fatty acids, mainly arachidonic and eicosapentanoic acid. 
In recent years, there has been an increasing interest on the seaweed varieties along the Kenya coast, therefore their characterization by De Clerck et al., (2000). An estimated 386 species of seaweeds were identified including 214 rhodophytes, 116 chlorophytes and 56 phaeophytes (Bolton et al., 2007). While the consumption of seaweeds has seen an increasing trend in Asia and some Western countries, their utilization in Africa has not been fully established (Dawczynski et al., 2007). Notwithstanding, the growing knowledge on the nutritional benefits of seaweeds has led to a focus on the utilization of seaweeds as sources of proteins in the previously low consumption regions (Fleurence, 1999). Recently, Mwalugha et al., (2015) attempted to characterize the seaweed varieties available on the Kenya coast in terms of their proximate composition. However, far too little attention has been paid to the nutritional composition of this seafood. Currently, there are no reliable sources on the fatty acids, mineral composition and functional properties of the seaweeds found on the Kenyan Marine resources. Therefore, the aim of this study was to investigate the chemical composition and functional properties on five selected seaweeds from the Kenya coast.

\section{Materials and Methods}

\subsection{Study Area}

The seaweeds were collected near Mombasa along the Kenya coast (Latitude $4^{\circ} 3^{\prime} 0^{\prime}$ 'S and Longitude $39^{\circ} 40^{\prime} 0$ '”).

\subsection{Seaweed Sample Collection and Preparation}

Five seaweed species (Hypnea musciformis, Eucheuma denticulatum, Laurencia intermedia, Sargassum oligocystum,Ulva fasciata) were collected at the intertidal zone near Mombasa. The five seaweeds were the dominant species in terms of biomass in the study area. The seaweed samples were handpicked and immediately washed using seawater to remove any foreign particles. The clean samples were kept in buckets and transported to Kenya Marine and Fisheries Research Institute (KEMFRI) laboratories in Mombasa for identification and drying. Thereafter, a second washing was carried out on the samples using deionized water to remove surface adhering salts. The seaweeds were then sun dried,ground into a powder and refrigerated at $4^{0} \mathrm{C}$ until further analysis. The collected seaweed voucher species are preserved at the department of Food Science and Technology in JKUAT. Analytical grade chemicals were purchased for analysis.

\subsection{Proximate Analysis}

The moisture content, crude ash, crude fat, crude protein and crude fiber of the seaweed samples were determined according to the official method of analysis of AOAC international, (2000). The moisture content was determined by oven drying method at $105^{\circ} \mathrm{C}$ where two grams of the sample were used. Crude ash content was analysed by incineration where five grams of the sample were ashed in an electric muffle furnace (Shimadzu $\mathrm{KL}-420$, Japan) at $550{ }^{\circ} \mathrm{C}$ for $16 \mathrm{~h}$ to a constant weight. The crude fat was extracted from five grams of the algal sample using the Soxhlet apparatus with petroleum ether as the solvent and determined gravimetrically after oven-drying at $70^{\circ} \mathrm{C}$ for 1 hour.

The crude protein content of seaweeds was determined according to the Kjeldahl method and conversion factor of 6.25 was used to calculate the crude protein content from the nitrogen content.

The crude fibre was determined by sequential digestion of seaweed samples with $1.25 \% \mathrm{H}_{2} \mathrm{SO}_{4}$ and $1.25 \%$ $\mathrm{NaOH}$ using the fibreglass as a container. For drying and ashing, the crucible with the sample was dried in an oven for 5 hours at $105^{\circ} \mathrm{C}$ and ashed in the muffle furnace at $550^{\circ} \mathrm{C}$ for 16 hours. The weight of crucible with sample after drying and ashing was recorded and the crude fibre content was calculated.

The NFE were calculated based on weight difference using crude protein, crude fat, crude fibre, and crude ash and data as follows.

$$
\mathrm{NFE} \%=100-(\text { crude fibre }+ \text { crude protein }+ \text { crude ash }+ \text { crude fat })
$$

\subsection{Fatty Acid Analysis}

The fatty acid profile of the seaweed samples was determined by gas chromatography after fat extraction using modified Bligh and Dyer method (1959). One gram of algal sample was put in a 50ml glass stoppered centrifuge tube. Methanol and chloroform were then added in a ratio of 2:1. The contents were centrifuged at 30,000 rpm for 10 minutes. The supernatant was transferred to a conical flask and $15 \mathrm{mls}$ of chloroform was added to the remnant. The contents were centrifuged at $30,000 \mathrm{rpm}$ for 10 minutes and supernatant one and two were combined and then passed through a defatted cotton wool. The contents were then put in a rotary flask and evaporated to dryness. Five millilitres of $95 \%$ methanol and $5 \%$ hydrochloric acid were added followed by refluxing at $100^{\circ} \mathrm{C}$ for 1 hour. The contents were then cooled in running water before transferring to a separating 
funnel where $10 \mathrm{ml}$ of hexane was added followed by shaking vigorously. The contents were then left to settle where the upper layer of hexane was collected in a conical flask and the lower layer was further re extracted using hexane and the two hexane layers were mixed. The hexane layer were put in a separating flask and washed with water. The contents were then passed through a plugged funnel with cotton cool and anhydrous sodium sulphate. The contents were evaporated in a rotary evaporator to $0.5-1 \mu \mathrm{l}$ and put in vials. $1 \mu \mathrm{l}$ of the sample was drawn and injected into a gas chromatography (GC) (Shimadzu GC-9A, No. 41991A - Japan). Known concentrations of fatty acids standards were fed into the $\mathrm{GC}$ and identification done by comparing the retention time. The percentage fatty acid composition was determined using Eq. (2).

Fatty acid $\%=((\text { Peak area of fatty acid/ (Total peak area of fatty acids-Peak area of Hexane }))^{*} 100$

Eq. (2)

\subsection{Mineral Analysis}

The mineral content of seaweeds was determined by the dry ash method. Two grams of the algal samples were ashed at $550-600^{\circ} \mathrm{C}$ for 2 hours then diluted using $1 \mathrm{~N} \mathrm{HCl}$ and filtered using Whatman filter paper no. 4. The absorbance of the standards followed by the samples was determined using an atomic absorbance spectrophotometer (Shimadzu, AA-6200-Japan).

\subsection{Emulsifying Activity (EA) and Water Holding Capacity}

The emulsion activity of seaweed samples was determined using a modification of the method described by Naczk et al., (1986). Two gram of seaweed powder was dissolved in $20 \mathrm{~mL}$ of distilled water then the suspension was vortexed for $10 \mathrm{~min}$ using (Vortex mixer model TM- 151 -Japan). At the $5^{\text {th }}$ minute, $20 \mathrm{~mL}$ of corn oil was added continuously with stirring. The emulsion was then centrifuged at $2100 \mathrm{rpm}$ for $10 \mathrm{~min}$ at $25^{\circ} \mathrm{C}$ (Beckman CS-6 centrifuge). The Volume of the emulsified layer was then recorded and the emulsion activity was calculated according to $\mathrm{Eq}(3)$

$$
\text { EA\% }=(\text { volume of emulsified layer/ volume of the suspension }) * 100
$$

The water holding capacity (WHC) was determined according to AACC (1983) as the maximum amount of water retained by one gram of sample under low-speed centrifugation (2060 rpm for $10 \mathrm{~min}$; Beckman CS-6 centrifuge) at $25^{\circ} \mathrm{C}$. Only enough water was added to saturate the sample and not to cause a liquid phase. All analyses were conducted in triplicates.

\subsection{Data Analysis}

All data were expressed as mean \pm standard error. Data concerning chemical and functional properties for seaweed species were analysed using one-way analysis of variance (ANOVA) and the means were separated using Duncans multiple range test (DMRT) using the statistical package for social scientists (SPSS $®$ ) Ver. 20.

\section{Results and Discussion}

\subsection{Proximate Composition}

The proximate composition revealed that NFE formed the highest mean component in seaweeds (Table 1). The results indicated that seaweed varieties of Hypnea musciformis and Sargassum oligocystum had the highest levels of NFE at 73.07 and $71.42 \%$ respectively. The NFE values for Hypnea musciformis were considerably higher than those reported by Siddique, (2013) and Mwalugha et al., (2015), who obtained 20.60\% and 43.76\% respectively. In addition, the NFE values for Sargassum oligocystum was higher than 53.21\% reported by Azad and Xiang, (2012) and 30.30\% reported by Kumar et al.,(2011). These variation could be attributed to differences in biological, physical, and environmental factors (i.e. harvest period), which are related to the difference in species, habitat and seasonality (Marinho-Soriano et al., 2006). The least proximate component was crude fat $(0.87 \%)$, where Eucheuma denticulatum had the highest value among the five seaweed species. The crude fat content of Eucheuma denticulatum was within the range of (1-6\%) (Fleurence et al., 1994) and close to (1.5\%) reported by Kumar et al., (2011) in Kappaphycus alvarezii (Eucheuma cottonii) from the Indian coast. Additionally, the value was close to (1.10\%) reported by Matanjun et al., (2009) in Eucheuma cottonii from Malaysia. The other species recorded the lowest amount of crude fat which was close to $0.48 \%$ obtained by Azad \& Xiang, (2012). 
Table 1 . The proximate composition ( $\%$ dry weight) of seaweed species from the Kenya coast (mean \pm SE, $n=3$ )

\begin{tabular}{lccccc}
\hline Seaweed species & Ash & Crude fiber & Crude fat & Crude protein & Nitrogen Free Extract (NFE) \\
\hline Eucheuma denticulatum & $27.13 \pm 1.46^{\mathrm{c}}$ & $5.22 \pm 1.67^{\mathrm{a}}$ & $1.78 \pm 0.67^{\mathrm{b}}$ & $5.06 \pm 0.36^{\mathrm{a}}$ & $60.81 \pm 1.95^{\mathrm{ab}}$ \\
Hypnea musciformis & $12.79 \pm 2.58^{\mathrm{a}}$ & $6.49 \pm 1.21^{\mathrm{ab}}$ & $0.77 \pm 0.17^{\mathrm{a}}$ & $6.88 \pm 1.22^{\mathrm{b}}$ & $73.07 \pm 0.22^{\mathrm{c}}$ \\
Laurencia intermedia & $25.62 \pm 1.36^{\mathrm{c}}$ & $7.50 \pm 0.79^{\mathrm{b}}$ & $0.47 \pm 0.17^{\mathrm{a}}$ & $8.48 \pm 0.41^{\mathrm{c}}$ & $57.93 \pm 0.20^{\mathrm{a}}$ \\
Sargassum oligocystum & $13.08 \pm 2.74^{\mathrm{a}}$ & $9.40 \pm 1.39^{\mathrm{c}}$ & $0.46 \pm .0 .07^{\mathrm{a}}$ & $5.64 \pm 0.19^{\mathrm{ab}}$ & $71.42 \pm 2.13^{\mathrm{c}}$ \\
Ulva fasciata $^{\mathrm{c}}$ & $19.92 \pm 3.42^{\mathrm{b}}$ & $7.10 \pm 0.32^{\mathrm{b}}$ & $0.86 \pm 0.11^{\mathrm{a}}$ & $10.06 \pm 0.90^{\mathrm{d}}$ & $62.06 \pm 3.10^{\mathrm{b}}$ \\
\hline
\end{tabular}

Means with different superscript letters in each column are significantly different at $p<0.05$.

Eucheuma denticulatum and Laurencia intermedia had the highest ash content which differed with $(36.21 \%)$ and (30.32\%) obtained by Mwalugha et al., (2015). Similarly, the ash content of Hypnea musciformis differed with (21.57\%) reported by Siddique, (2013) and (20.77\%) reported by Mwalugha et al., (2015). In this study the ash content of Sargassum oligocystum was considerably lower than $24.88 \%$ reported by Azad and Xiang, (2012) and (42.40\%) in Sargassum polycystum obtained by Matanjun et al., (2009). The variation in ash content could be related to habitat, the habitats may have varying amounts of inorganic compounds and salts, additionally, temperature and $\mathrm{pH}$ could have an influence on mineralization (Mendis \& Kim, 2011; Polat \& Ozogul, 2009).

Crude fiber accounts for the indigestible components of the seaweed (Dawczynski et al., 2007). Sargassum oligocystum recorded the highest amount of crude fiber which varied slightly with (7.74\%) obtained by Marinho-Soriano et al., (2006) and (7.58\%) reported by Azad and Xiang, (2012). Eucheuma denticulatum and Hypnea musciformis recorded the lowest amount of crude fiber. The crude fiber of Eucheuma denticulatum was similar to (5.91\%) in Eucheuma cottonii obtained by Matanjun et al., (2009). The variation in crude fiber content could be attributed to differences in photosynthetic activity, growth stage and seasonality which is as a result of changes in the environment that influences photosynthesis and nutrient absorption (Siddique, 2013; Wong \& Cheung, 2000).

The crude protein of Ulva fasciata was in line with (7.31\%) obtained by Frikha et al., (2011) and (10.69\%) reported by Tabarsa et al., (2012). The crude protein of Eucheuma denticulatum was slightly lower than (9.76\%) obtained by Matanjun et al., (2009). The protein content of Sargassum oligocystum was in agreement with (5.63\%) reported by Mwalugha et al., (2015). The variation in protein content in seaweeds could be attributed to differences in seasonality and growth conditions in the environment (Dawczynski et al., 2007).

\subsection{Mineral Composition}

Table 2. Mineral composition $(\mathrm{mg} / 100 \mathrm{~g})$ of seaweed species from the Kenya coast (mean $\pm \mathrm{SE}, n=3$ )

\begin{tabular}{llllll}
\hline Seaweed species & Hypnea musciformis & Sargassum oligocystum & Ulva fasciata & Eucheuma denticulatum & Laurencia intermedia \\
\hline Minerals & & & & & \\
Sodium & $20.50 \pm 5.61^{\mathrm{b}}$ & $18.79 \pm 1.82^{\mathrm{b}}$ & $17.42 \pm 2.43^{\mathrm{b}}$ & $9.88 \pm 1.25^{\mathrm{a}}$ & $21.88 \pm 0.71^{\mathrm{b}}$ \\
Potassium & $2.55 \pm 0.18^{\mathrm{c}}$ & $0.50 \pm 0.03^{\mathrm{a}}$ & $2.56 \pm 0.10^{\mathrm{c}}$ & $1.36 \pm 0.25^{\mathrm{b}}$ & $0.75 \pm 0.06^{\mathrm{a}}$ \\
Phosphorus & $2.21 \pm 0.53^{\mathrm{a}}$ & $3.35 \pm 0.24^{\mathrm{a}}$ & $2.36 \pm 0.49^{\mathrm{a}}$ & $2.43 \pm 1.35^{\mathrm{a}}$ & $2.96 \pm 1.03^{\mathrm{a}}$ \\
Magnesium & $411.56 \pm 7.66^{\mathrm{b}}$ & $397.12 \pm 2.19^{\mathrm{a}}$ & $429.88 \pm 2.47^{\mathrm{c}}$ & $436.97 \pm 1.06^{\mathrm{c}}$ & $445.09 \pm 2.68^{\mathrm{d}}$ \\
Zinc & $1.29 \pm 0.23^{\mathrm{a}}$ & $1.51 \pm 0.22^{\mathrm{a}}$ & $4.12 \pm 0.30^{\mathrm{b}}$ & $4.25 \pm 1.85^{\mathrm{b}}$ & $0.99 \pm 0.11^{\mathrm{a}}$ \\
Iron & $7.34 \pm 1.71^{\mathrm{a}}$ & $25.82 \pm 1.34^{\mathrm{b}}$ & $51.39 \pm 2.58^{\mathrm{c}}$ & $48.80 \pm 1.0^{\mathrm{d}}$ & $30.71 \pm 1.27^{\mathrm{c}}$ \\
Cadmium & $0.17 \pm 0.01^{\mathrm{a}}$ & $0.18 \pm 0.05^{\mathrm{ab}}$ & $0.24 \pm 0.05^{\mathrm{ab}}$ & $0.30 \pm 0.10^{\mathrm{b}}$ & $0.21 \pm 0.05^{\mathrm{ab}}$ \\
Lead & $\mathrm{nd}$ & $\mathrm{nd}$ & $\mathrm{nd}$ & $\mathrm{nd}$ & $\mathrm{nd}$ \\
\hline
\end{tabular}

nd $=$ not detected $($ LOD for lead $=0.0692 \mathrm{ppm}$ )

Means with different superscript letters in each row are significantly different at $p<0.05$.

Among the nine minerals analysed calcium was the dominant mineral followed by magnesium (Table 2), similarly Calcium and Magnesium were found to be the major minerals in brown and red seaweeds (Rupérez, 2002). Eucheuma denticulatum recorded the highest amount of calcium while Hypnea musciformis had the lowest amount ( $\mathrm{p}$ 0.001). The calcium content of Eucheuma denticulatum was considerably higher than (442 $\mathrm{mg} / 100 \mathrm{~g}$ ) in Eucheuma spp obtained by Krishnaiah et al., (2008). The calcium content in all the seaweed species was substantially higher compared to lettuce $(35 \mathrm{mg} / 100 \mathrm{~g})$, cabbage $(40 \mathrm{mg} / 100 \mathrm{~g})$ and spinach $(99 \mathrm{mg} / 100 \mathrm{~g})$ (USDA, 2016). From these findings, seaweeds showed a potential of being utilized as a supplement of vegetables in the human diet. Calcium plays a key role in construction and maintenance of bones and ensuring normal functioning of muscles and nerves (Soetan et al., 2010). Seaweeds have been found to possess diverse 
mineral content due to their habitat in the marine environment. As a result of this, minerals such as calcium are able to accumulate in much higher content compared to terrestrial plants (MacArtain et al., 2007). This could potentially explain why calcium was among the dominant minerals in the seaweed species.

The highest levels of magnesium was recorded in Laurencia intermedia $(445.09 \mathrm{mg} / 100 \mathrm{~g}$ ), while Sargassum oligocystum had the lowest at $397.12 \mathrm{mg} / 100 \mathrm{~g}$. The content of magnesium in Laurencia intermedia obtained in the current study was lower than $(640 \mathrm{mg} / 100 \mathrm{~g})$ reported by Kumar et al., (2011) in Laurencia cruciata. In addition, the level of magnesium in Sargassum oligocystum was lower than $487.81 \mathrm{mg} / 100 \mathrm{~g}$ reported by Matanjun et al., (2009) in Sargassum polycystum. $700 \mathrm{mg} / 100 \mathrm{~g}$ ) obtained in Sargassum swartzii (Kumar et al., $2011)$ and $(1160 \mathrm{mg} / 100 \mathrm{~g})$ reported in Sargassum echinocarpum by McDermid et al., (2007). Magnesium is a cofactor for enzymes involved in important biochemical pathways in the human body (Soetan et al., 2010).

Ulva fasciata and Hypnea musciformis had the highest levels of potassium while Laurencia intermedia and Sargassum oligocystum had the lowest. The potassium content of Ulva fasciata was lower than $520 \mathrm{mg} / 100 \mathrm{~g}$ reported by Rohani-Ghadikolaei et al., (2012) in Ulva Lactuca, 2450mg/100g reported by MacArtain et al., (2007) and $4340 \mathrm{mg} / 100 \mathrm{~g}$ obtained by Kumar et al., (2011) in Ulva species. The potassium content of Laurencia intermedia was considerably lower than $(6040 \mathrm{mg} / 100 \mathrm{~g})$ reported by Kumar et al., (2011) in Laurencia cruciate.

High Zinc content was reported in Eucheuma denticulatum and Ulva fasciata while the rest of the species had the lowest amount. The Zinc content of the seaweed species $(0.4-1.7 \mathrm{mg} / 100 \mathrm{~g})$ was within the range reported for seaweeds. The Zinc content of Eucheuma denticulatum was slightly higher than $(0.545 \%)$ in Eucheuma isiforme obtained by Robledo \& Freile Pelegrin, (1997) and lower than (6.63\%) in Eucheuma spp reported by Krishnaiah et al., (2008). The variation in mineral composition could be attributed to the difference in geographical location (Rao et al., 2007), and also difference in species. For instance, seaweeds bioaccumulate a lot of minerals and are a good source of Magnesium, Iron, Iodine and other trace elements (MacArtain et al., 2007).

There was no significant difference in the Cadmium content among the seaweed species $(\mathrm{p}=0.163)$. The Cadmium content in Ulva fasciata was higher than $(0.05 \mathrm{mg} / 100 \mathrm{~g})$ reported by Topçuoğlu et al., (2001) in Ulva lactuca and a range of 0.0031-0.0033mg/100g reported by Besada et al., (2009). The Cadmium content of Sargassum oligocystum was lower than $(0.70 \mathrm{mg} / 100 \mathrm{~g})$ in Sargassum wightii stem and higher than $(0.14 \mathrm{mg} / 100 \mathrm{~g})$ in Sargassum polycystum stem (Jothinayagi \& Anbazhagan 2009). The presence of Cadmium could be attributed to water contamination by sewage, effluent from metal product manufacturers, fertilizers and by- products from oil refining (Wong et al., 1982).

\subsection{Fatty Acids Composition}

Table 3. Fatty acid profile of seaweed species from the Kenya coast (mean \pm SE, $n=3$ )

\begin{tabular}{|c|c|c|c|c|c|}
\hline Fatty acids (\%) & Eucheuma denticulatum & Hypnea musciformis & Laurencia intermedia & Sargassum oligocystum & Ulva fasciata \\
\hline Caprylic (C8:0) & $0.31 \pm 0.54^{\mathrm{a}}$ & $0.07 \pm 0.13^{\mathrm{a}}$ & nd & $0.33 \pm 0.50^{\mathrm{a}}$ & $0.26 \pm 0.45^{\mathrm{a}}$ \\
\hline Capric (C10:0) & $2.62 \pm 4.54^{\mathrm{a}}$ & $36.09 \pm 24.14^{b}$ & $13.37 \pm 1.05^{\mathrm{a}}$ & $11.40 \pm 10.06^{\mathrm{a}}$ & $23.40 \pm 1.75^{\mathrm{ab}}$ \\
\hline Lauric (C12:0) & $0.34 \pm 0.31^{\mathrm{ab}}$ & $0.22 \pm 0.37^{\mathrm{ab}}$ & $1.81 \pm 0.21^{\mathrm{bc}}$ & $0.02 \pm 0.04^{\mathrm{a}}$ & $2.09 \pm 1.81^{\mathrm{c}}$ \\
\hline Myristic (C14:0) & $4.24 \pm 0.39^{c}$ & $2.08 \pm 0.87^{b}$ & $6.09 \pm 0.06^{\mathrm{d}}$ & $4.50 \pm 0.23^{\mathrm{c}}$ & $0.72 \pm 0.63^{\mathrm{a}}$ \\
\hline Palmitic (C16:0) & $43.22 \pm 17.76^{\mathrm{b}}$ & $21.06 \pm 3.88^{\mathrm{a}}$ & $46.88 \pm 0.37^{b}$ & $41.56 \pm 3.27^{\mathrm{b}}$ & $34.74 \pm 3.85^{\text {ab }}$ \\
\hline Stearic (C18:0) & $2.30 \pm 1.06^{\mathrm{a}}$ & $4.60 \pm 0.58^{\mathrm{a}}$ & $2.90 \pm 0.07^{\mathrm{a}}$ & $2.86 \pm 0.32^{\mathrm{a}}$ & $4.28 \pm 1.85^{\mathrm{a}}$ \\
\hline Arachidic (C20:0) & nd & nd & nd & $0.95 \pm 0.58^{b}$ & $3.24 \pm 0.45^{\mathrm{c}}$ \\
\hline $\mathrm{SFA}^{1}$ & $53.72 \pm 11.55^{\mathrm{a}}$ & $64.12 \pm 20.82^{\mathrm{a}}$ & $71.04 \pm 0.49^{\mathrm{a}}$ & $61.63 \pm 6.17^{\mathrm{a}}$ & $68.73 \pm 0.41^{\mathrm{a}}$ \\
\hline Oleic (C18:1) & $4.83 \pm 3.43^{\mathrm{a}}$ & $8.41 \pm 1.64^{\mathrm{b}}$ & $11.22 \pm 0.13^{\mathrm{b}}$ & $17.71 \pm 1.12^{\mathrm{c}}$ & $11.77 \pm 1.55^{\mathrm{b}}$ \\
\hline MUFA $^{2}$ & $4.83 \pm 3.43^{\mathrm{a}}$ & $8.41 \pm 1.64^{\mathrm{b}}$ & $11.22 \pm 0.13^{\mathrm{b}}$ & $17.71 \pm 1.12^{\mathrm{c}}$ & $11.77 \pm 1.55^{\mathrm{b}}$ \\
\hline Linoleic (C18:2) & $2.27 \pm 1.50^{\mathrm{a}}$ & $3.27 \pm 2.43^{\mathrm{a}}$ & $2.70 \pm 0.19^{\mathrm{a}}$ & $6.33 \pm 0.23^{\mathrm{b}}$ & $3.81 \pm 0.94^{\mathrm{a}}$ \\
\hline Linolenic (C18:3) & $0.49 \pm 0.18^{\mathrm{a}}$ & $1.48 \pm 1.41^{\mathrm{a}}$ & $0.37 \pm 0.15^{\mathrm{a}}$ & $3.80 \pm 0.56^{\mathrm{b}}$ & $5.64 \pm 0.77^{\mathrm{c}}$ \\
\hline PUFA $^{3}$ & $2.75 \pm 2.10^{\mathrm{a}}$ & $4.75 \pm 3.84^{\mathrm{a}}$ & $3.07 \pm 0.06^{\mathrm{a}}$ & $10.13 \pm 0.79^{b}$ & $9.45 \pm 1.69^{\mathrm{b}}$ \\
\hline
\end{tabular}

nd $=$ not detected

${ }^{1}$ Total saturated fatty acids (SFA) $=$ the sum of $\mathrm{C} 8$ to $\mathrm{C} 20$.

${ }^{2}$ Total mono unsaturated fatty acids (MUFA) $=$ the amount of C18:1

${ }^{3}$ Total poly unsaturated fatty acids (PUFA) $=$ the sum of $\mathrm{C} 18: 2$ and $\mathrm{C} 18: 3$

Means with different superscript letters within the rows are significantly different at $p<0.05$.

The fatty acid composition of the seaweed species varied from $0.07 \%$ to $46.88 \%$ in SFA. The total saturated fatty acids ranged from 53.72 to $71.04 \%$ however there was no significance difference among the species. In this study, the total saturated fatty acids in Sargassum oligocystum (61.63\%) was higher than the value reported by 
Kumari et al., (2013) (49.6\%). Total saturated fatty acids of Ulva fasciata (68.73\%) was close to (68.97\%) reported for Ulva lactuca by Yaich et al., (2011) however the value was higher than (38.50\% ) reported in Ulva species ( Durmaz et al., 2008). Palmitic acid was the most dominant saturated fatty acid, Hypnea musciformis (21.06\%) and Ulva fasciata (34.74\%) recorded the lowest amount of palmitic acid while the rest of the species had the highest $(\mathrm{P}<0.027)$. The results of this study were in agreement with that of Gressler et al., (2010) who reported palmitic acid as the dominant saturated fatty acid in seaweeds.

Sargassum oligocystum had the highest amount of total Mono Unsaturated Fatty acids (MUFA) (17.71\%) and Eucheuma denticulatum had the lowest amount of total MUFA $(4.83 \%)(\mathrm{P}<0.001)$. The total MUFA in Sargassum oligocystum was within the range reported in seaweeds by Van Ginneken et al., (2011) (3-56\%). The total MUFA in Eucheuma denticulatum was within the range of 1.8-12.5\% (Khotimchenko et al., 2002), however the total MUFA of Eucheuma denticulatum was lower than the range reported in seaweeds by Gressler et al., (2010) (6.6-10.5\%). The variation in MUFA content could be as a result of exclusion of palmitoleic and eicosenoic fatty acids.

The total polyunsaturated fatty acids (PUFA) included Linoleic acid and Linolenic acid. Sargassum oligocystum and Ulva fasciata recorded the highest amount of PUFA (10.13\%) and (9.45\%) respectively which are lower than the range reported by Dawczynski et al., (2007) (34 -74\%). The PUFAs in Ulva fasciata (9.45\%) was considerably lower than $(33.76 \%)$ reported by Durmaz et al., (2008) similarly the value in this study was lower than $(56.9 \%)$ obtained in Ulva lactuca (Khotimchenko et al., 2002). Eucheuma denticulatum, Hypnea musciformis and Laurencia intermedia recorded the lowest amount of PUFAs (Table 3) ( $<<0.003)$, the total PUFA in Laurencia intermedia was lower than (70.5\%) reported in Laurencia okamuria (Li et al., 2002) and (16.7\%) obtained in Laurencia filiformis (Gressler et al., 2010). The total PUFA in Eucheuma denticulatum was lower than (26.97\%) reported in Kappaphycus alvarezii (Eucheuma cottonii) (Kumar et al., 2011). Arachidic acid was only found in Sargassum oligocystum and Ulva fasciata. The difference in the fatty acid among the seaweed is related to difference in species and habitat (Khotimchenko et al., 2002). Additionally, the difference in PUFAs could be attributed to environmental temperature since algae normally accumulates PUFAs when there is a decrease in environmental temperature (Kayama et al., 1985). The incorporation of seaweed in low salt meat emulsion models was shown to increase the PUFA content (López-López et al., 2009), this shows the potential of seaweed as a substrate in food processing.

\subsection{Emulsion Activity}

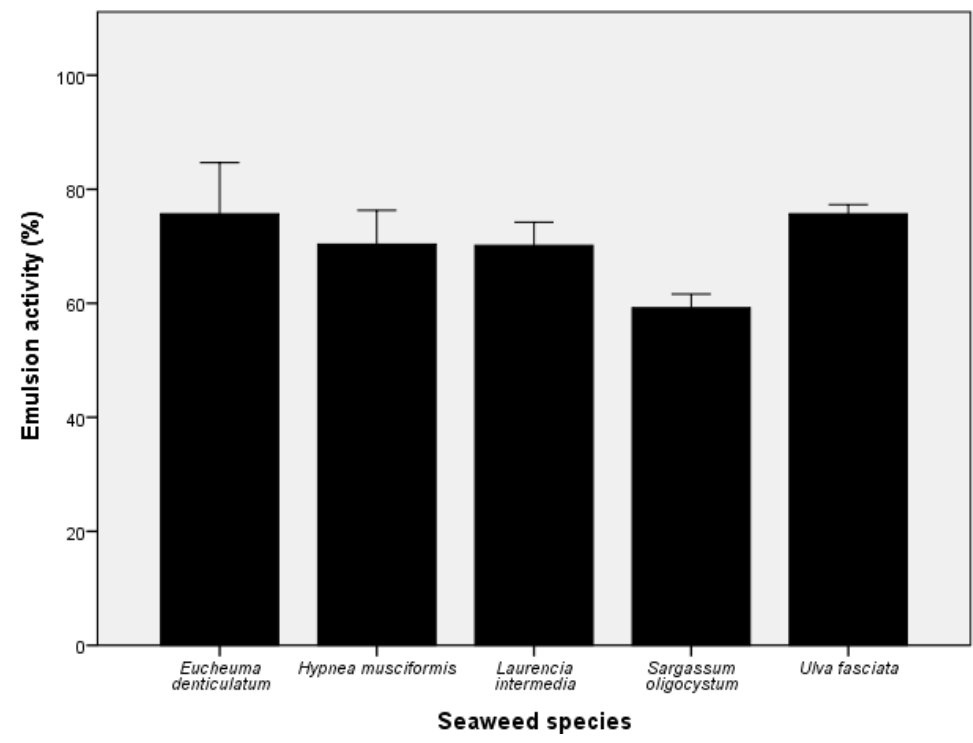

Figure 1. Emulsion activity (\%) of seaweed species from the Kenya coast (mean \pm SE, $n=3$ )

The emulsion activity of the seaweed species ranged from $59.19 \%$ to $75.69 \%$ (Figure 1) with Eucheuma denticulatum (75.68\%) and Ulva fasciata (75.66\%) recording the highest values and Sargassum oligocystum (59.19\%) recording the lowest value $(\mathrm{P}<0.001)$. The emulsion activity of Eucheuma denticulatum was similar to (75.68\%) in Kappaphycus alvarezii (Eucheuma cottonii) obtained by Kumar et al., (2014) where cotton seed oil was used. In this study the emulsion capacities of the seaweed species compares well with lupin seed (60\%) and soya bean (70\%) whose extract are used as emulsifiers in the food industry (Tömösközi et al., 2001). The good 
emulsifying ability of seaweeds is attributed to phycocolloids which is widely used in meat processing as a result of their good thickening, emulsifying, thickening and stabilizing properties (Cofrades et al., 2011).

\subsection{Water Holding Capacity}

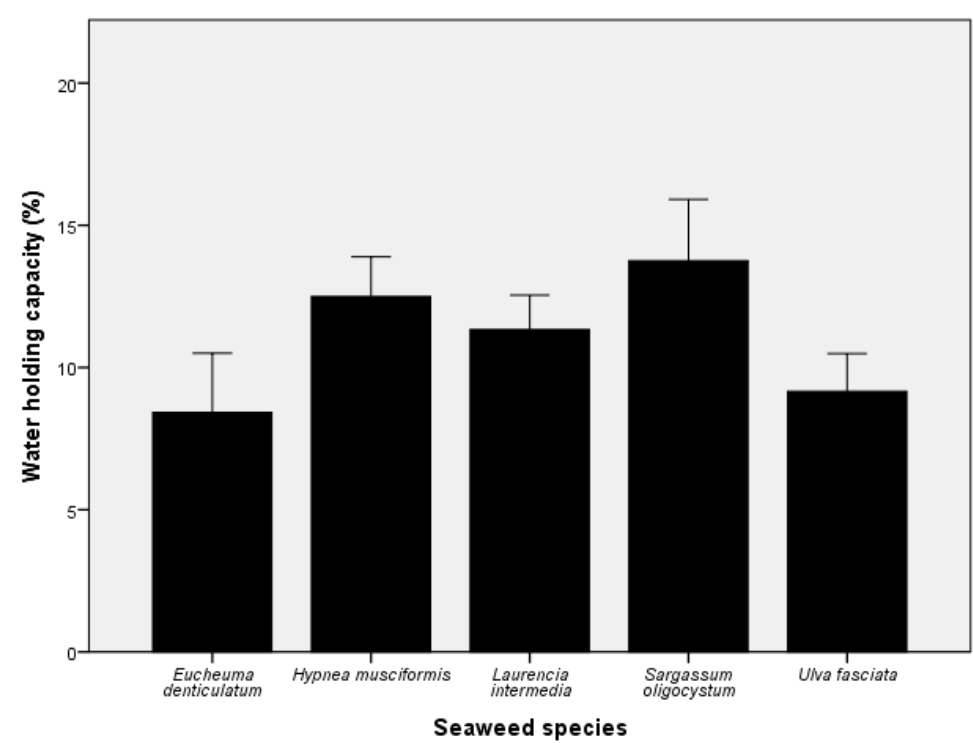

Figure 2. Water holding capacity $(\mathrm{ml} / \mathrm{g}$ ) of of seaweed species from the Kenya coast (mean $\pm \mathrm{SE}, n=3$ )

Sargassum oligocystum $(13.75 \mathrm{ml} / \mathrm{g})$ recorded the highest water holding capacity while the lowest was recorded in Eucheuma denticulatum $(8.42 \mathrm{ml} / \mathrm{g}$ ) and Ulva fasciata $(9.16 \mathrm{ml} / \mathrm{g}$ ) (Figure 2; $\mathrm{P}<0.001)$. The water holding capacity of Ulva fasciata reported in this study was higher than $(6.66-7.00 \mathrm{ml} / \mathrm{g}$ ) reported in Ulva lactuca (Yaich et al., 2011). The water holding capacity of Eucheuma denticulatum was lower than $(17.7 \mathrm{ml} / \mathrm{g})$ in Eucheuma powder (Senthil et al., 2005). The water holding capacity of the seaweed species was slightly higher than the range reported for commercial dietary fibre supplements $(6.60-9.00 \mathrm{ml} / \mathrm{g}$ ) (Goñi \& Martin-Carrón, 1998). The variation in water holding capacity could be as a result of varying fibre and protein content of the seaweeds that have an influence on the functional properties (Fleurence, 1999; Yaich et al., 2011). In this study Sargassum oligocystum had the highest crude fiber and considerably high amount of crude protein while Eucheuma denticulatum had the lowest crude fiber and crude protein (Table 1). Seaweeds have been shown to improve the water holding capacity of emulsions, this consequently has had an influence on hardness and chewiness of cooked products (Cofrades et al., 2008).

\section{Conclusions}

This study has revealed that Kenya seaweeds could be a good source of dietary fibre, proteins and nitrogen free extract (NFE). The seaweeds have potentially good mineral content especially calcium and magnesium compared to lettuce, cabbage and spinach. For this reason, seaweeds could be consumed as food supplement to aid in achieving the recommended daily intake of macro and trace minerals. Lead was not detected in the seaweed species however cadmium was detected. In the seaweed species the SFA were the highest followed by MUFA and finally PUFA. Emulsion activity and water holding capacity are among the key functional properties of food ingredients. Seaweed have been utilized as gelling agent and stabilizers in the pharmaceutical and food industry. The emulsion activity of the seaweeds were similar to that of soybean and even higher than that of lupin seeds. The water holding capacities of the seaweeds were relatively higher than that of commercial fibre products. These characteristics show that seaweeds can be incorporated in food products to provide nutrients as well as improve the physiochemical properties, specifically Eucheuma denticulatum due to its high total mineral composition, high emulsion activity and availability. Further research should be conducted to investigate functional properties and other parameters such as phytochemical and antioxidant properties of other seaweeds along the Kenyan coast.

\section{Acknowledgments}

We thank Japan International Cooperation Agency (JICA), the Research Production and Extension (JKUAT) and the Department of Food Science and Technology of JKUAT for providing the funding ,facilities and technical support. 


\section{References}

Approved methods of the American Association of Cereal Chemistry [AACC]. (1983). (8th Ed.) St. Paul, MN: American Association of Cereal Chemistry (Method 88-04).

Association of Official Analytical Chemists [AOAC] international. (2000). Arlington; Official Methods of Analysis.

Azad, S. A., \& Xiang, T. Z. (2012). Suitability of Seaweed Meal Incorporated with Rhodovulum sp. Bacterium as Feed Supplement for Finfish Larvae. Borneo Science, 30, 57-61.

Besada, V., Andrade, J. M., Schultze, F., \& González, J. J. (2009). Heavy metals in edible seaweeds commercialised for human consumption. Journal of Marine Systems, 75(1), 305-313. https:/doi.org/10.1016/j.jmarsys.2008.10.010

Benjama, O., \& Masniyom, P. (2011). Nutritional composition and physicochemical properties of two green seaweeds (Ulva pertusa and U. intestinalis) from the Pattani Bay in Southern Thailand. Songklanakarin Journal of Science and Technology, 33(5), 575-583.

Bligh, E. G., \& Dyer, W. J. (1959). A rapid method for total lipid extraction and purification. Canadian Journal Biochemistry Physiology, 37, 911-917. https:/doi.org/10.1139/o59-099

Bolton, J. J., Oyieke, H. A., \& Gwada, P. (2007). The seaweeds of Kenya: Checklist, history of seaweed study, coastal environment, and analysis of seaweed diversity and biogeography. South African Journal of Botany, 73(1), 76-88. http://doi.org/10.1016/j.sajb.2006.08.006.

Cofrades S., Lopez-L, Opez, I., \&Ruiz-Capillas, C. et al. (2011) Quality characteristics of low-salt restructured poultry with microbial transglutaminase and seaweed. Meat Sci., 87, 373-380. https:/doi.org/10.1016/j.meatsci.2010.11.014

Cofrades, S., López-López, I., Solas, M. T., Bravo, L., \& Jiménez-Colmenero, F. (2008). Influence of different types and proportions of added edible seaweeds on characteristics of low-salt gel/emulsion meat systems. Meat Science, 79(4), 767-776. https:/doi.org/10.1016/j.meatsci.2007.11.010

Dawczynski, C., Schubert, R., \& Jahreis, G. (2007). Amino acids, fatty acids, and dietary fibre in edible seaweed products. Food Chemistry, 103(3), 891-899. http://doi.org/10.1016/j.foodchem.2006.09.041

Dawes, C. J. (1998). Marine botany. New York, NY: John Wiley \& Sons.

De Clerck, O., Dargent, O., Leliaert, F., \& Coppejans, E. (2000). Progress of the taxonomic research on the macroalgae (Chlorophyta, Phaeophyta and Rhodophyta) along the East African coast.

Durmaz, Y., Duyar, H. A., Gökpinar, S., Taskaya, L., Öğretmen, Y. O., Bandarra, N. M., \& Nunes, M. L. (2008). Fatty Acids, $\alpha$-tocopherol and total pigment contents of Cystoseira spp., Ulva spp. and Zostera spp. from Sinop Bay (Turkey). International Journal of Natural and Engineering Sciences, 2(3), 111-114.

Frikha, F., Kammoun, M., Hammami, N., Mchirgui, R. A., Belbahri, L., Gargouri, Y., \& Ben-Rebah, F. (2011). Chemical composition and some biological activities of marine algae collected in Tunisia Composición química y algunas actividades biológicas de algas marinas recolectadas en Túnez. Ciencias Marinas, 37(2), 113-124. https:/doi.org/10.7773/cm.v37i2.1712

Fleurence, J. (1999). Seaweed proteins: Biochemical, nutritional aspects and potential uses. Trends in Food Science and Technology, 10(1), 25-28. http://doi.org/10.1016/S0924-2244(99)00015-1

Fleurence, J., Gutbier, G., Mabeau, S., \& Leray, C. (1994). Fatty acids from 11 marine macroalgae of the French Brittany coast. Journal of Applied Phycology, 6(5-6), 527-532. http://doi.org/10.1007/BF02182406

Goñi, I., \& Martin-Carrón, N. (1998). In vitro fermentation and hydration properties of commercial dietary fiber-rich supplements. Nutrition Research, 18(6), 1077-1089. https:/doi.org/10.1016/S0271-5317(98)00090-6

Gressler, V., Yokoya, N. S., Fujii, M. T., Colepicolo, P., Filho, J. M., Torres, R. P., \& Pinto, E. (2010). Lipid, fatty acid, protein, amino acid and ash contents in four Brazilian red algae species. Food Chemistry, 120(2), 585-590. http://doi.org/10.1016/j.foodchem.2009.10.028

Gupta, S., \& Abu-Ghannam, N. (2011). Recent developments in the application of seaweeds or seaweed extracts as a means for enhancing the safety and quality attributes of foods. Innovative Food Science \& Emerging Technologies, 12(4), 600-609. https:/doi.org/10.1016/j.ifset.2011.07.004

Jothinayagi, N., \& Anbazhagan, C. (2009). Heavy metal monitoring of Rameswaram coast by some Sargassum 
species. American-Eurasian Journal of Scientific Research, 4(2), 73-80.

Kayama, M., Iijima, N., Kuwahara, M., Sado, T., Araki, S., \& Sakurai, T. (1985). Effect of water temperature on the fatty acid composition of Porphyra spp. Nippon Suisan Gakkaishi, 51(4), 680-687. https:/doi.org/10.1016/j.foodchem.2009.11.006

Khotimchenko, S. V., Vaskovsky, V. E., \& Titlyanova, T. V. (2002). Fatty acids of marine algae from the Pacific coast of North California. Botanica Marina, 45(1), 17-22. https:/doi.org/10.1515/BOT.2002.003

Krishnaiah, D., Sarbatly, R., Prasad, D. M. R., \& Bono, A. (2008). Mineral content of some seaweeds from Sabah's South China Sea. Asian Journal of Scientific Research, 1(2), 166-170. https:/doi.org/10.3923/ajsr.2008.166.170

Kumar, K. S., Ganesan, K., Selvaraj, K., \& Rao, P. S. (2014). Studies on the functional properties of protein concentrate of Kappaphycus alvarezii (Doty) Doty-An edible seaweed. Food chemistry, 153, 353-360. https:/doi.org/10.1016/j.foodchem.2013.12.058

Kumar, M., Kumari, P., Trivedi, N., Shukla, M. K., Gupta, V., Reddy, C. R. K., \& Jha, B. (2011). Minerals, PUFAs and antioxidant properties of some tropical seaweeds from Saurashtra coast of India. Journal of Applied Phycology, 23(5), 797-810. https:/doi.org/10.1007/s10811-010-9578-7

Kumari, P., Bijo, A. J., Mantri, V. A., Reddy, C. R. K., \& Jha, B. (2013). Fatty acid profiling of tropical marine macroalgae: An analysis from chemotaxonomic and nutritional perspectives. Phytochemistry, 86, 44-56. http://doi.org/10.1016/j.phytochem.2012.10.015

Kumari, P., Kumar, M., Gupta, V., Reddy, C. R. K., \& Jha, B. (2010). Tropical marine macroalgae as potential sources of nutritionally important PUFAs. Food Chemistry, 120(3), 749-757. http://doi.org/10.1016/j.foodchem.2009.11.006

Li, X., Fan, X., Han, L., \& Lou, Q. (2002). Fatty acids of some algae from the Bohai Sea. Phytochemistry, 59(2), 157-161. http://doi.org/10.1016/S0031-9422(01)00437-X

Lobban, C., Harrison, P., \& Duncan, M. 1985. The physiological ecology of seaweeds. New York, NY: Cambridge University Press.

López-López, I., Bastida, S., Ruiz-Capillas, C., Bravo, L., Larrea, M. T., Sánchez-Muniz, F., \& Jiménez-Colmenero, F. (2009). Composition and antioxidant capacity of low-salt meat emulsion model systems containing edible seaweeds. Meat Science, 83(3), 492-498. https:/doi.org/10.1016/j.meatsci.2009.06.031

MacArtain, P., Gill, C. I., Brooks, M., Campbell, R., \& Rowland, I. R. (2007). Nutritional value of edible seaweeds. Nutrition Reviews, 65(12), 535-543. https:/doi.org/10.1111/j.1753-4887.2007.tb00278.x

Marinho-Soriano, E., Fonseca, P. C., Carneiro, M. A. A., \& Moreira, W. S. C. (2006). Seasonal variation in the chemical composition of two tropical seaweeds. Bioresource Technology, 97(18), 2402-2406. https:/doi.org/10.1016/j.biortech.2005.10.014

Matanjun, P., Mohamed, S., Mustapha, N. M., \& Muhammad, K. (2009). Nutrient content of tropical edible seaweeds, Eucheuma cottonii, Caulerpa lentillifera and Sargassum polycystum. Journal of Applied Phycology, 21(1), 75-80. http://doi.org/10.1007/s10811-008-9326-4

Mendis, E., \& Kim, S. K. (2011). Present and future prospects of seaweeds in developing functional foods. Advances in Food and Nutrition Research, 64, 1-15. https:/doi.org/10.1016/B978-0-12-387669-0.00001-6

McDermid, K. J., Stuercke, B., \& Balazs, G. H. (2007). Nutritional composition of marine plants in the diet of the green sea turtle (Chelonia mydas) in the Hawaiian Islands. Bulletin of Marine Science, 81(1), 55-71. https:/doi.org/10.1016/j.tifs.2011.09.001

Mohamed, S., Hashim, S. N., \& Rahman, H. A. (2012). Seaweeds: A sustainable functional food for complementary and alternative therapy. Trends in Food Science and Technology, 23(2), 83-96. http://doi.org/10.1016/j.tifs.2011.09.001

Mwalugha, H. M., Wakibia, J. G., Kenji, G. M., \& Mwasaru, M. A. (2015). Chemical composition of common Seaweeds from the Kenya Coast. Journal of Food Research, 4(6), 28-35. http://doi.org/10.5539/jfr.v4n6p28

Naczk, M., Rubin, L. J., \& Shahidi, F. (1986). Functional properties and phytate content of pea protein preparations. Journal of Food Science, 51(5), 1245-1247.

https:/doi.org/10.1111/j.1365-2621.1986.tb13096.x 
Ortiz, J., Romero, N., Robert, P., Araya, J., Lopez-Hernández, J., Bozzo, C., Rios, A. (2006). Dietary fiber, amino acid, fatty acid and tocopherol contents of the edible seaweeds Ulva lactuca and Durvillaea antarctica. Food Chemistry, 99(1), 98-104. http://doi.org/10.1016/j.foodchem.2005.07.027

Polat, S., \& Ozogul, Y. (2009). Fatty acid, mineral and proximate composition of some seaweeds from the northeastern Mediterranean coast. Italian Journal of Food Science, 21(3), 317-324.

Rao, P. V. S., Mantri, V. A., \& Ganesan, K. (2007). Mineral composition of edible seaweed Porphyra vietnamensis. Food Chemistry, 102(1), 215-218. http://doi.org/10.1016/j.foodchem.2006.05.009

Robledo, D., \& Freile Pelegrin, Y. (1997). Chemical and mineral composition of six potentially edible seaweed species of Yucatan. Botanica Marina, 40(1-6), 301-306. https:/doi.org/10.1515/botm.1997.40.1-6.301

Rohani-Ghadikolaei, K., Abdulalian, E., \& Ng, W. K. (2012). Evaluation of the proximate, fatty acid and mineral composition of representative green, brown and red seaweeds from the Persian Gulf of Iran as potential food and feed resources. Journal of Food Science and Technology, 49(6), 774-780. https:/doi.org/10.1007/s13197-010-0220-0

Rupérez, P. (2002). Mineral content of edible marine seaweeds. Food Chemistry, 79(1), 23-26. https:/doi.org/10.1016/S0308-8146(02)00171-1

Senthil, A., Mamatha, B. S., \& Mahadevaswamy, M. (2005). Effect of using seaweed (Eucheuma) powder on the quality of fish cutlet. International journal of food sciences and nutrition, 56(5), 327-335. https:/doi.org/10.1080/09637480500224205

Siddique, M. A. M. (2013). Proximate chemical composition and amino acid profile of two red seaweeds (Hypnea pannosa and Hypnea musciformis) collected from st. Martin's island, Bangladesh. Journal of Fisheries Sciences, 7(2), 178-186. http://doi.org/10.3153/jfscom.2013018

Soetan, K. O., Olaiya, C. O., \& Oyewole, O. E. (2010). The importance of mineral elements for humans, domestic animals and plants-A review. African Journal of Food Science, 4(5), 200-222.

Tabarsa, M., Rezaei, M., Ramezanpour, Z., \& Waaland, J. R. (2012). Chemical compositions of the marine algae Gracilaria salicornia (Rhodophyta) and Ulva lactuca (Chlorophyta) as a potential food source. Journal of the Science of Food and Agriculture, 92(12), 2500-2506. http://doi.org/10.1002/jsfa.5659

Tömösközi, S., Lásztity, R., Haraszi, R., \& Baticz, O. (2001). Isolation and study of the functional properties of pea proteins. Journal of Molecular Nutrition and Food Research, 45(6), 399-401. https:/doi.org/10.1002/1521-3803(20011001)45:6<399::aid-food399>3.0.co;2-0

Topçuoğlu, S., Güven, K. C., Kırbaşoğlu, Ç., Güngör, N., Ünlü, S., \& Yılmaz, Y. Z. (2001). Heavy metals in marine algae from Şile in the Black Sea, 1994-1997. Bulletin of Environmental Contamination and Toxicology, 67(2), 288-294. https:/doi.org/10.1007/s00128-001-0123-x

United States Department of Agriculture (USDA) (2016). National Nutrient Database for Standard Reference Release 28. https://ndb.nal.usda.gov/ndb/search/list.

Van Ginneken, V. J., Helsper, J. P., de Visser, W., van Keulen, H., \& Brandenburg, W. A. (2011). Polyunsaturated fatty acids in various macroalgal species from north Atlantic and tropical seas. Lipids in Health and Disease, 10(1), 594-619. https:/doi.org/10.1186/1476-511x-10-104

Wong, K. H., \& Cheung, P. C. (2000). Nutritional evaluation of some subtropical red and green seaweeds: Proximate composition, amino acid profiles and some physico-chemical properties. Food Chemistry, 71(4), 475-482. https:/doi.org/10.1016/S0308-8146(00)00175-8

Wong, M. H., Kwok, T. T., \& Ho, K. C. (1982). Heavy metals in Ulva lactuca collected within Tolo Harbour, an almost landlocked sea. Hydrobiological Bulletin, 16(2-3), 223-230. https:/doi.org/10.1007/BF02255376

Yaich, H., Garna, H., Besbes, S., Paquot, M., Blecker, C., \& Attia, H. (2011). Chemical composition and functional properties of Ulva lactuca seaweed collected in Tunisia. Food Chemistry, 128(4), 895-901. http://doi.org/10.1016/j.foodchem.2011.03.114

\section{Copyrights}

Copyright for this article is retained by the author(s), with first publication rights granted to the journal.

This is an open-access article distributed under the terms and conditions of the Creative Commons Attribution license (http://creativecommons.org/licenses/by/4.0/). 